\title{
IMPACT OF HIV AND AIDS ON HOUSEHOLD FOOD AND NUTRITION SECURITY IN SUBA DISTRICT, KENYA
}

Musita CP*1 ${ }^{1}$, Ariga $\mathrm{ES}^{2}$, Kaseje $\mathrm{DK}^{1}$ and A Otieno ${ }^{1}$

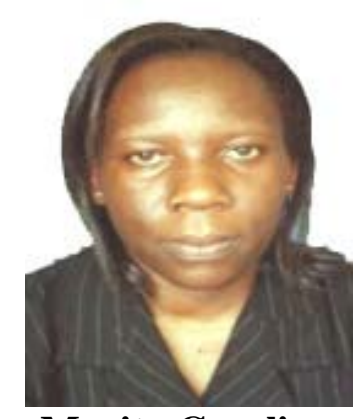

Musita Caroline

*Corresponding Author email: mucapa2002@yahoo.com and c.musita@gluk.ac.ke

${ }^{1}$ Great Lakes University of Kisumu, P.O.Box2224,Kisumu,Kenya.

${ }^{2}$ University of Nairobi, P.O.Box 20953, Nairobi, Kenya. 


\section{ABSTRACT}

The impact of HIV/AIDS on household food and nutrition security in Suba district was studied in a quasi longitudinal study. Households with People Living with HIV/AIDS (Index- 25\%) and three surrounding households (control- 75\%) were considered for the study. Data were collected on demographic characteristics of the households, land ownership, cultivated land by crop, crop yield, livestock kept by category, diet composition, frequency of hunger, experience of weight loss in the households and expenditure on food. Categorization among the index households was based on disease progression stages: Stage 1(with no symptoms), Stage 2 (Symptomatic-(CD4>200, CD4 <200) and on antiretroviral, Stage 3( bedridden patients), and Stage 4 (households with HIV related deaths). Results showed households with bedridden members had the highest land ownership of more than 3 acres (62 per cent), while those with CD4 $<200$ and on ARVs had the least land (28 per cent). The proportion of index households with uncultivated land was 3 times higher than control households. Index households significantly planted less maize but equally planted beans, sorghum/millet, cassava, groundnuts and tomatoes, whose yields were comparatively less. Control (non index) households kept more goats, sheep, cattle and chicken than index households. Households that had suffered HIV related deaths had lower overall rate of expenditure on food due to reduction in household income. Death increased household consumption of home produced food partially making up for the lost income. The incidence of hunger was found to be slightly higher among the controls with chronically ill (65 per cent) than among index households (63 per cent). Eating of non balanced food and loss of weight in the last one month was significantly higher in index than non index households. The mean expenditure on food was also less in index (8.5 US \$) than non index households (9.2 US \$). It is imperative, therefore, that appropriate intervention measures be put in place to combat food and nutrition insecurity among People Living with HIV/AIDS and their families in order for them to benefit from the life prolonging effects of ARVs.

Key words: Food, Nutrition, HIV/AIDS, Households, Effect 


\section{INTRODUCTION}

HIV/AIDS continues to be the most crippling and devastating disease creating havoc throughout the world. By the end of 2004, there were about $36-43$ million people living with HIV/AIDS throughout the world, of whom 25.4 million were estimated to be living in sub-Saharan Africa [1]. The Kenyan government has attempted to control the pandemic through increased political commitment, information education and communication, increased allocation of funding, availability of treatment programmes and prevention efforts [2]. Despite these efforts the pandemic continues to adversely affect the 15-24- year age group in sub Saharan Africa [3].

In Nyanza province, HIV/AIDS has adversely affected agricultural human resources and outputs leading to an increasing number of female-headed households [4]. From these grim statistics, it is important to understand the economic impact of the pandemic on People Living with HIV/AIDS (PLWHAs) with reference to access to Essential Elements of Dignified Livelihoods (EEDL).

HIV/AIDS diminishes the household's ability to produce food because it kills mostly productive adults. This has impacted negatively on the agricultural labour force, which makes up most of the labour force of the affected countries. The Food and Agriculture Organization (FAO) states that millions of agricultural workers have died in twenty five affected countries in Africa as a result of HIV/AIDS [5]. The effect of sickness and death may result in less time being spent on the farms and less land being cultivated; ultimately output and productivity decline. A study on commercial farms in Kenya showed decline in labour productivity due to absenteeism arising from workers' morbidity and funeral attendance [6]. In Tanzania, Kadonya found that women spent $60 \%$ less time on agricultural activities because their husbands were ill [7]. A study in Uganda found that coffee was abandoned due to inability to maintain enough labour for both intensive food crops to less intensive ones of lower nutritional value.

A Tanzanian study found that per capita food consumption decreased by $15 \%$ after death of an adult in the poorest households [5]. The cost of HIV/AIDS epidemic on households is also felt through the large number of deaths affecting younger income earners (15-50 years). Households that have suffered death have lower overall rate of expenditure due to reduction in household income and increased household consumption of home produced food, but this only partially makes up for the lost income [5].

In addition to these, a study carried out in Ethiopia also revealed that the cost of caring for an AIDS patient, and meeting the subsequent funeral expenses, exceeded the average annual farm income [8]. Traditional safety nets which contribute to food security in times of need have broken down in worst affected communities and families and neighbors have become too overburdened to help each other with food, loans, a hand in the field, or care of orphans. Poor households sell their productive assets either to buy food or to feed mourners [8]. Another study in Uganda showed

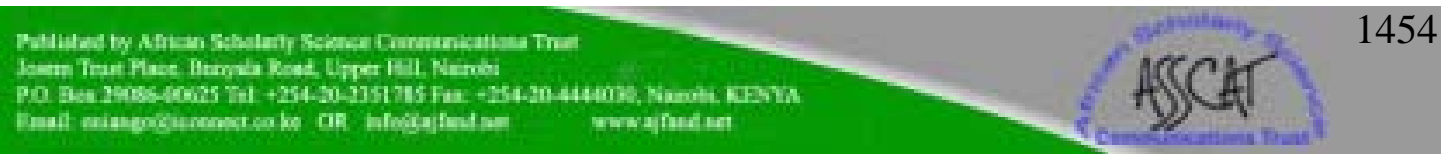


that $65 \%$ of the AIDS affected households were obliged to sell property to pay for care [9]. In Zimbabwe it was revealed that maize production in households with an AIDS death reduced by $61 \%$ whereas cotton, vegetables and groundnuts production declined by 47, 49 and $37 \%$, respectively [10].

Access to assets such as land depends on gender, socio-economic status and age. These assets increase the scope for coping strategies for food insecure households. In many rural African societies, AIDS widows, most of whom are infected with the virus may have no legal rights to land and property after a husband's death, due to customary or even formal inheritance laws [11]. Majority of husbands die interstate leaving impoverished widows who are forced to send their children away due to inability to care for them and sometimes engage in occasional transactional sex. Moreover, the stigma associated with HIV/AIDS may not allow the infected person to disclose their status without facing social exclusion. A study done in Uganda revealed that food insecurity and malnutrition are more rampant in female-headed AIDS affected households [11].

Studies conducted in Uganda, Tanzania and Zambia have shown that HIV/AIDS follows a different pattern in each village and district [12]. Geographic and ethnic factors, religion, gender, age, marriage, customs and agro-ecological conditions play a role in the pattern and impact of HIV/AIDS and in people's perception of the disease. The pandemic may also affect economic growth through fragmentation of savings into health care and consumption thereby reducing investment. According to Kenya's Sessional Paper no. 4 [11], AIDS kills young economically productive people. Evidence shows that 58\% of staff deaths in the Ministry of Agriculture and Rural Development are caused by AIDS while Zambia lost 1,300 teachers in the first ten months of 1998 to AIDS, the equivalent of around two thirds of all new teachers trained annually [5]. HIV/AIDS may affect food security at national level, through the decrease in labour force, worker productivity and total agricultural output. Reduced food supplies can lead to a rise in food prices. The effect on commercial enterprise may undermine the country's capacity to export and generate foreign exchange thereby reducing ability of the country to import food when needed. HIV/AIDS is currently reducing annual GDP growth by $0.8 \%$ in Africa [5].

AIDS poses a significant threat to household food security and nutrition. HIV infection and associated clinical complications have tremendous effect on the nutritional status of an individual [13]. Current literature on the interactions of nutrition, infectious disease process and immune dysfunction demonstrates that these factors interact with each other [13]. The disease is associated with symptoms that cause a reduction in the amount of food consumed. This could be due to inability to eat or swallow because of painful sores in the mouth and throat, loss of appetite due to fatigue, depression and other changes in the mental state, side effect of medications such as nausea, loss of appetite, metallic taste in the mouth, diarrhea, vomiting and abdominal cramps [13]. 
Decreased food consumption can also result from reduced quantity and quality of food in the household as a result of the inability to work or reduced income because of HIV- related illness [14]. If nutrition interventions are put in place early in the course of the disease, it is possible to avoid or counteract HIV-related depletion of nutrient stores, malnutrition, weight loss and wasting which can be life threatening. The impact begins early in the course of HIV infection even before other symptoms are observed. Although nutrition counseling is offered in major public hospitals in Kenya and probably other developing countries, not all HIV patients get access to this service and therefore still suffer from diseases of nutrition [14].

Due to decrease in food consumption, studies have also shown that HIV/AIDS worsens micronutrient deficiencies in both men and women in the reproductive phase. In women this effect is compounded by pregnancy, lactation, menstruation and heavy workload that increase women's requirements for various nutrients [13]. HIV/AIDS has also been found to cause deficiencies of total calories, protein, vitamins A, B6, B12, C, E, magnesium, iron, selenium, and zinc [15]. Although micronutrient needs of People Living with HIV/AIDS (PLWHAS) is increased, it is recommended that they should not exceed two times the Recommended Daily Allowance (RDA) [15].

The number of servings required for calorie adequacy in HIV/AIDS patients is higher compared to other nutrients. It is recommended that adding an extra 300 calories and 10 grams of protein daily and vitamin A rich foods can help to increase the immune system function [13]. Metabolism and nutrient needs change with the onset of any infection. A number of metabolic, biochemical and hormonal responses favor protein catabolism and altered fluid and electrolyte balance during infections.

Factors that contribute to negative nitrogen balance include increased loss of urinary nitrogen during catabolism, increased resting metabolic expenditure during fever and limited intake of food as a result of anorexia. Losses of potassium, magnesium and phosphorus during infection accompany nitrogen losses, retention of salt and water and shifts in plasma levels of certain minerals occur. Plasma, zinc and iron levels fall while copper increases [16].

Vitamin A deficiency is common in HIV positive individuals. Lack of vitamin A is associated with compromised $\mathrm{T}$ - cells and $\mathrm{B}$ - cells function and pathological alterations of the mucosa surfaces thereby increasing the risk for opportunistic infections and increased progression of AIDS [17]. Therefore increased intake of vitamin A through dietary intake of fatty fish, liver, cheese, milk, fortified margarine and eggs is essential.

It is recommended that foods that have little nutritional value or those that may cause or speed up disease progression are best avoided [18]. The foods that may speed up disease progression include raw eggs, unpasteurized milk and dairy products (may have salmonella), undercooked meat and undercooked chicken (may have bacteria), "Junk" foods such as chips, biscuits, sweets with little nutritional value (sweets and sugar may promote the growth of fungi or thrush), alcohol and coffee which decrease

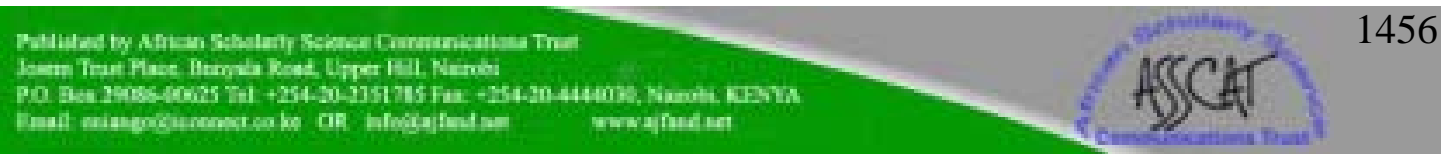


appetite and interfere with nutrient metabolism during digestion of food. Others include alcohol (which may also interact with medication and decrease their efficiency), smoking (which increases the amount of free radical in the body), expired foods, acidic foods, foods with preservatives and oily food (aggravate symptoms related to diarrhea, nausea or vomiting, loss of appetite and mouth and throat sores) [18].

\section{METHODOLOGY}

The study was a cross-sectional survey and applied quantitative data collection method. Data was collected using closed- ended questionnaires administered to household heads. Purposive sampling was used to select study sites. Suba district (Lambwe division) was selected due to its' high HIV/AIDS prevalence rates of $34 \%$. The study covered the whole Lambwe division. All households with PLWHAs (index) attending a patient support centre at the district hospital were listed. Simple random sampling was used to select a sample size of 195 households from the list [19].

The controls were selected randomly from households neighboring those with HIV/AIDS cases. A total of 566 control households were selected although some of them turned out later to be index households at the time of data collection. Data collection tools were developed, translated into Luo (spoken in Lambwe division) and back translated into English. Enumerators were trained and tools pre- tested before household heads were interviewed. Data were collected on demographic characteristics, land availability, crop production, livestock ownership and production, prevalence of hunger and frequency of hunger. Data were entered, cleaned and managed using Microsoft Excel program. Analysis was done using SPSS version 11. Ethical approval was obtained from the ethical review committee of The Great Lakes University of Kisumu. Household heads gave a signed consent prior to interview. All the categories of households in the index households (based on disease progression stages: Stage 1(with no symptoms), Stage 2 (Symptomatic-(CD4>200, CD4 <200) and on antiretroviral, Stage 3( bedridden patients), and Stage 4 (households with HIV related deaths).

\section{RESULTS}

\section{Demographic Characteristics of Index and Non Index Heads of Households}

Demographic characteristics of both index and non index households were analyzed (table 1). Household heads of non-index households were significantly older $(\mathrm{P}=0.004)$ than those of index households. The proportion of female heads of index households was higher (46\%) and those of non index (34\%). Out of index households, most $(25 \%)$ were in stage 2 of HIV/AIDS. Those in stages 1 and 3 were $23 \%$ and $22 \%$, respectively. Only $7 \%$ of PLWHAs were at stage 4 , which is terminal and requires care and support, while $23 \%$ of the households had experienced HIV related deaths

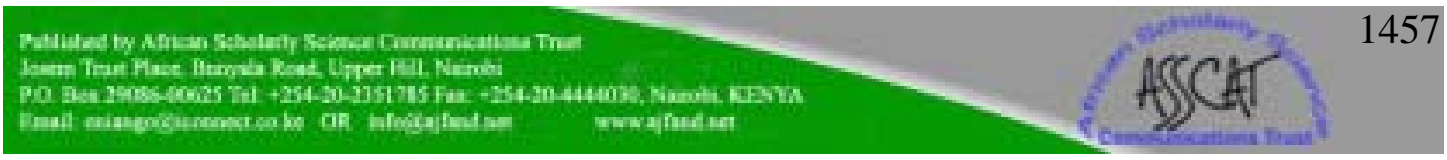


Education level is higher among the non-index households with $49 \%$ in secondary as compared to $13 \%$ among the index households. The reason is that among the index households, most of the family members drop out of school to provide care to the sick household members.

\section{Land Availability and Cultivation}

Figure 1 shows the relationship between distributions of land ownership by disease progression. Households with stage 4 individuals had the highest proportion (62\%) of those with land more than 3 acres while those in stage 3 with the lowest (28\%). As shown in Table 1.

Progression of the disease significantly affected land area under cultivation (table 2). Relatively higher proportion of households with individuals in Stage 3 (CD4 < 200 and on ARVs) did not cultivate any land (18\%) and $25 \%$ cultivated less than one acre compared to $3 \%$ and $18 \%$ of the controls, respectively. Households at Stages 2 (symptomatic, CD4 > 200) $9 \%$ and 3 (CD4 < $200 \&$ on ARVs) $13 \%$ cultivated more than 3 acres compared to $29 \%$ of the healthy controls. In the vertical comparison, with every increase in the stage of the disease, there was a general reduction in the acreage of the land cultivated. In addition, there was a general reduction in the proportion of those who put $>$ 3acres into cultivation with increase in the stage of infection. In the horizontal comparison, there was an increase in the proportion of households in the respective groups, peaking at 1-3 acres then falling at $>3$ acres. It is evident that the land cultivated was more than the land owned.

As shown in Table 2, households at Stage 3 of disease progression (CD4 $<200$ and on ARVs) registered the lowest of maize cultivation (73\%), beans (23\%) and sorghum/millet (58\%) compared to healthy controls with maize (92\%), beans (34\%) and sorghum/millet $(71 \%)$. There was tendency for households to switch to planting more sorghum/millet with disease progression (Table 3) as these crops require less labor. In the vertical comparison, there is a definite pattern on the cassava column. That is, with the increase in the stage of progression of the disease, there is reduction of proportion of those who planted the crop. This is attributed to the fact that cassava is a drought resistant crop also considered as a food security crop. Within the horizontal comparison, there is a tendency of the households cultivating crops that need less time to mature and relatively less labor in the production process. Among the index households, there is a tendency for those who are in the last stages of HIV/AIDS to select early maturing crops and less labor intensive crops (Table 3)

\section{Animals Production}

As depicted in Table 4, households with members in stages 4 and 5 appeared to own more goats $(>5)$ and chicken $(>6)$ than the controls. This is because, these types of the livestock are easier to rear, even in drought stricken areas, easy to translate into cash incase of need and require less labor.

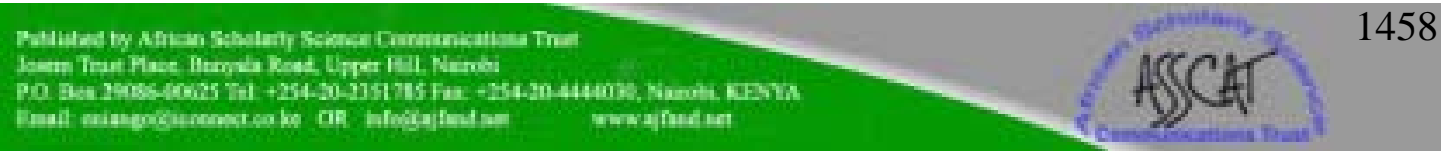




\section{Level of Hunger}

Figure 3 shows the relationship between frequencies of hunger by disease progression. It shows that households with stage 4 members and above experienced more hunger (92\%) than the controls (50\%). Figure 4 shows the prevalence of food shortages and frequency of occurrence at household level. Among the households, ninety-two of households in stage 4 experienced food shortages but only $31 \%$ had food shortages occurring more than 5 times in the past one month. Among the households with stage three, $75 \%$ experienced hunger and the majority (45\%) occurring more than 5 times in the past one month.

Figure 5 shows the relationship between households experiencing child hunger and disease progression. Households with members in stage 4 experienced most occurrences of children sleeping hungry for more than five times in the past thirty days.

\section{DISCUSSION}

The vulnerability of index households to food and nutrition insecurity is higher and this agrees with a study by Atieno [1] that showed that the number of female headed households is ever increasing due to HIV/AIDS in the region.

The effect of sickness and death may result in less time being spent on the farms and less land being cultivated; leading to a decline in productivity [4]. According to a study done by Kadonya [7] in Tanzania women spent $66 \%$ less time on agricultural activities because their husbands were ill, contributing to food insecurity [20]. In addition traditional safety nets, which contribute to food security in times of need are breaking down in the worst affected communities, where families and neighbors become too overburdened to help each other with food, loans, a hand in the field, or care of orphans.

According to a study done in Namibia there is widespread sale and slaughter of livestock to support the sick and provide food for the mourners, further jeopardizing the livestock industry and long-term food security [4]. In another study it was found that maize production in households with an AIDS death in Zimbabwe reduced by 61 percent whereas cotton, vegetables and groundnuts production declined by 47,49 and 37 percent, respectively [10].

This study also found that households with bed- ridden members had more land (62\%) with more than three acres while households with members in stage three had $28 \%$ with each having more than three acres. Access to assets such as land increases the scope for coping strategies for households. According to Oppong and Gosh, availability of land can be used as a strategy for intervention [3]. 
This study has shown that households with members at Stage 3 of disease progression recorded the lowest harvest of maize (73\%), beans (23\%) and sorghum/millet (58\%) compared to healthy controls with maize (92\%), beans $(34 \%)$ and sorghum/millet (71\%). There was tendency for households to switch to planting more sorghum/millet with disease progression. Therefore, planting other crops such as cassava, groundnuts and tomatoes can be used for income generation.

This study has also shown the frequency and recurrence of hunger was greater in index than non index HHs. This is not good for patients on ARVs who need more nutrients. In addition households with members in stage 4 also experienced most occurrences of children sleeping hungry for more than five times in the past thirty days and this may lead to diseases of malnutrition in these children.

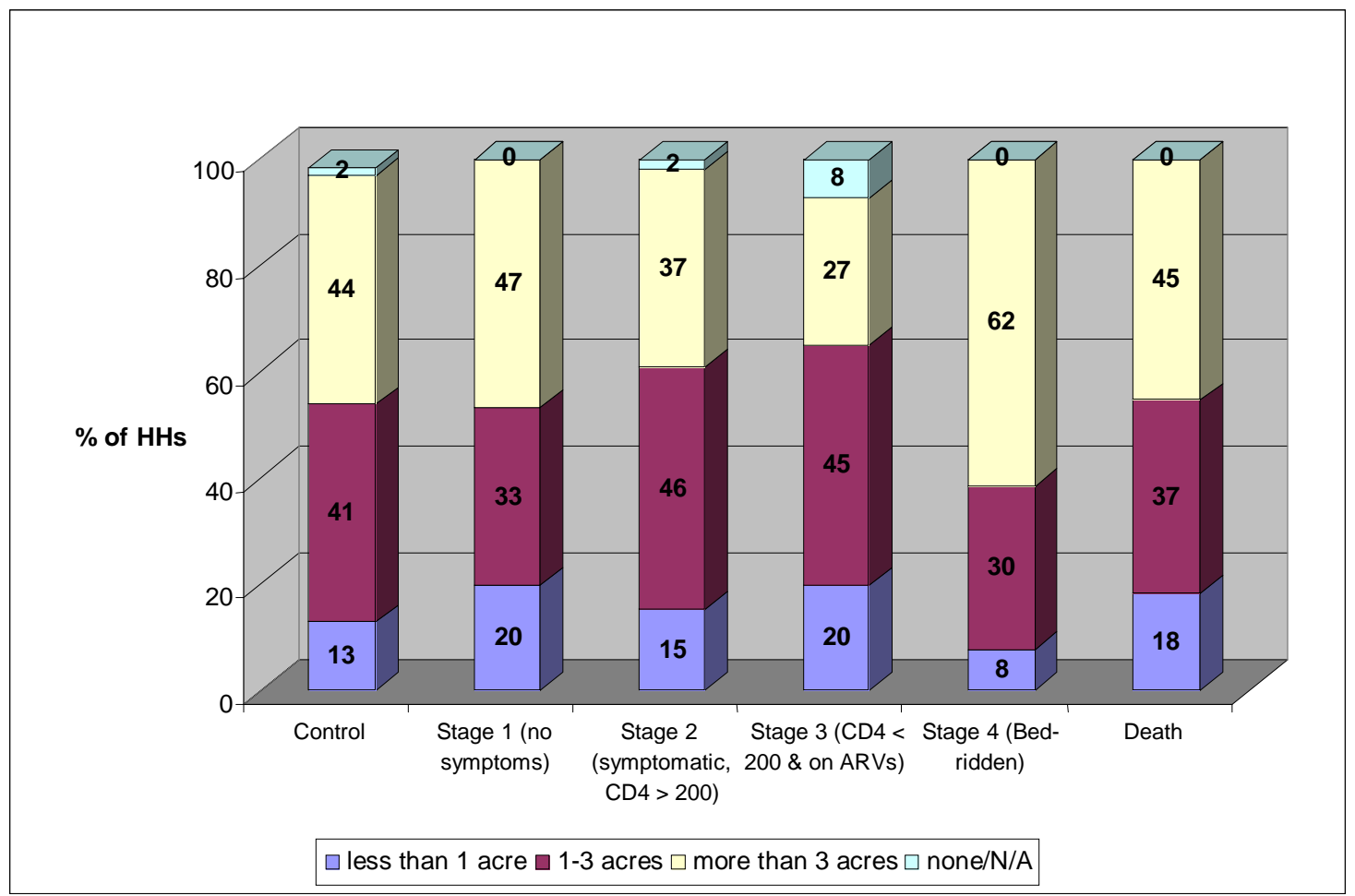

Figure 1: Distribution of land ownership by disease progression 


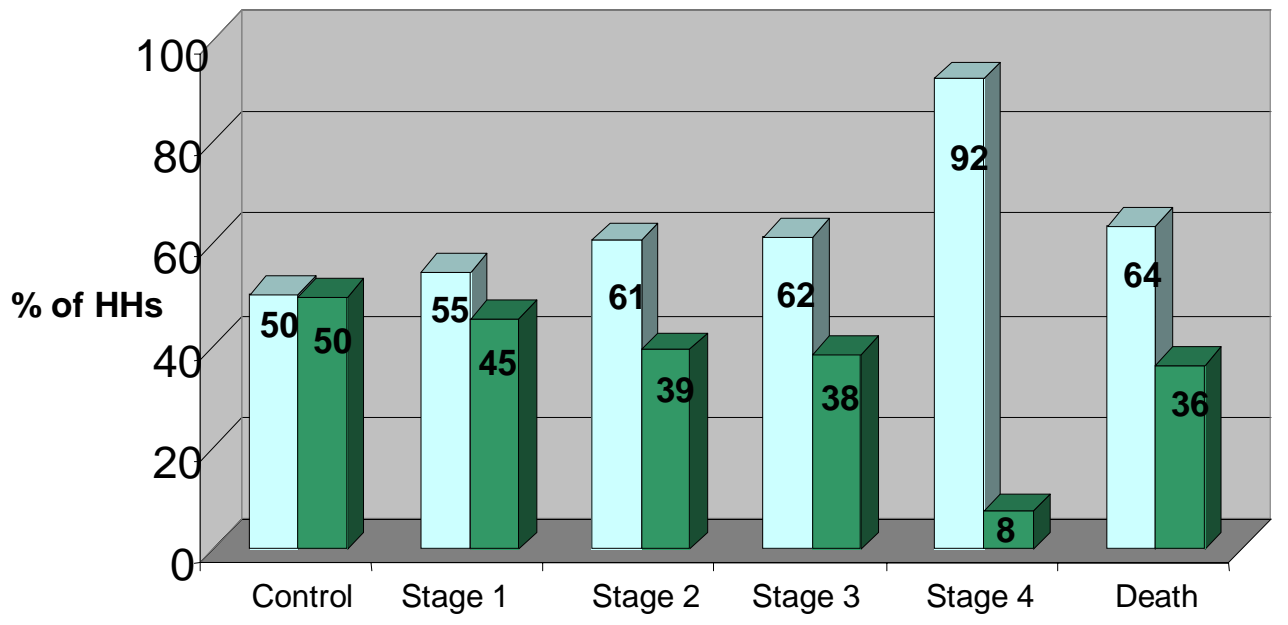

$\square$ Often $\square$ Never

Figure 2: Level of hunger among households by disease progression

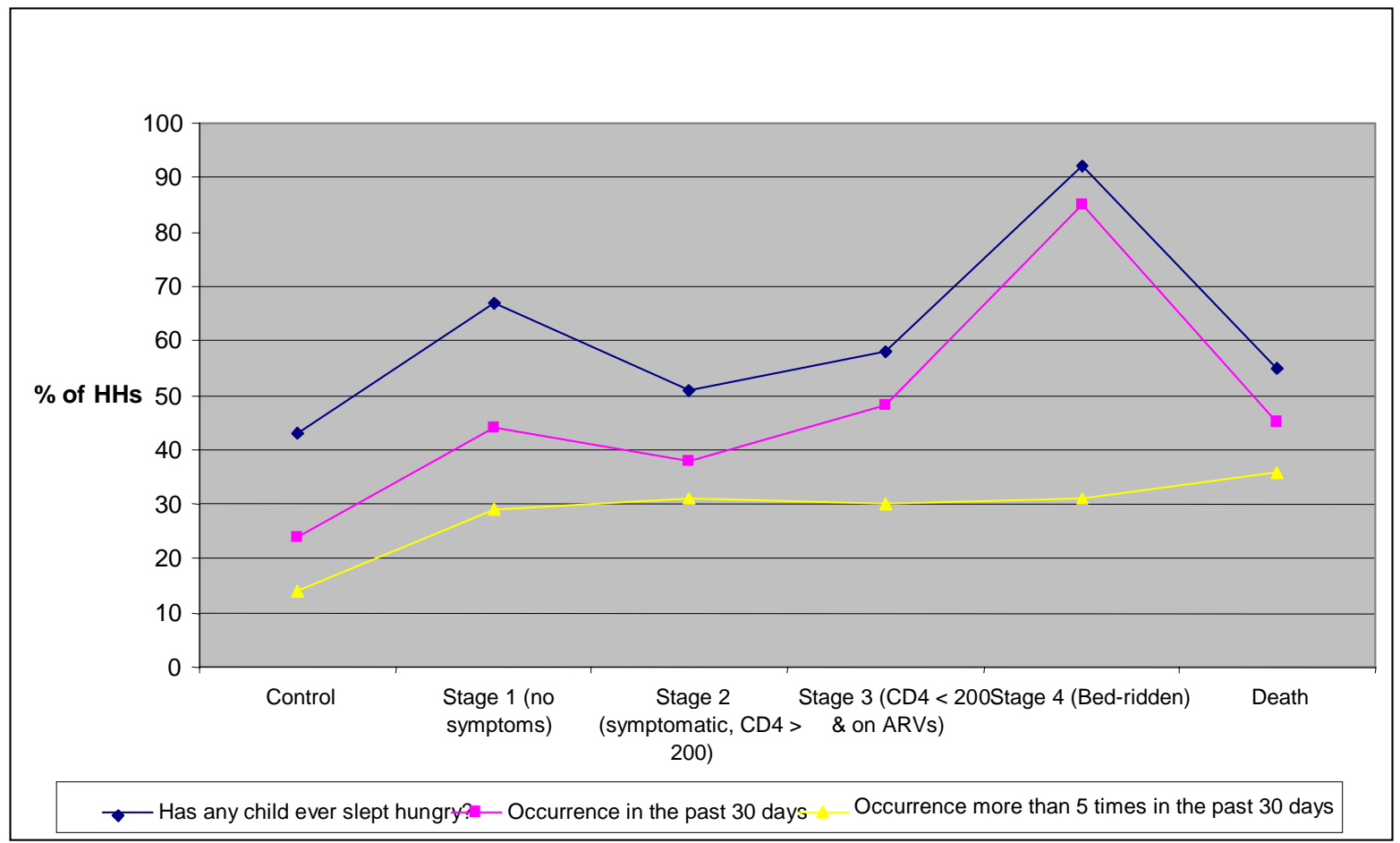

Figure 3: Child hunger among households by disease progression 


\section{CONCLUSION}

HIV/AID impacts negatively of food and nutrition security of the affected households in Suba district, Kenya. This is mainly as result of loss of active labour, un-sustained income, increased costs of medication and the overall disease burden in the household. As a result the affected households have adopted resilience methods such as planting less labour intensive crops, rearing and production of easy- to- maintain livestock such as poultry, sheep and goats.

In addition, the burden of HIV/AIDS significantly affects infected and affected households in terms of acreage of planting and low yields. This has led to increased planting of beans, millet and sorghum as a coping mechanism which require less input of labour. They also prefer small stock including sheep, goats and poultry and have a higher frequency of hunger. Poor nutrition that occurs in PLWHAs on ARVs results in exaggerated side- effects of the drugs resulting in poor recovery.

\section{RECOMMENDATION}

It is imperative, therefore, that appropriate intervention measures be put in place to combat food and nutrition insecurity among People Living with HIV/AIDS and their families in order to benefit from the life prolonging effects of ARVs. These could include fortified food supplements, subsidy on farm inputs and drip irrigation, labor saving technologies such as minimum or zero tillage techniques and rearing of small stock including indigenous poultry. 
Table 1: Demographic characteristics of index and non index households

\begin{tabular}{|l|c|c|}
\hline Variable & Index HH n=191 & Non index HH n=573 \\
\hline Age (P=0.004) & 42.4 & 46 \\
\hline Sex: Male $\quad$ Female & $54 \%$ & $66 \%$ \\
& $46 \%$ & $34 \%$ \\
\hline Stage of HIV/AIDS & & \\
1: No symptoms & $23 \%$ & \\
HIV/AIDS & $25 \%$ & \\
2.Symtomatic (CD4<200) & $22 \%$ & \\
3( CD4>200) and on ARVs & $7 \%$ & \\
4. Bedridden patients & $23 \%$ & \\
5.Household with & & \\
related deaths & & $52 \%$ \\
\hline Marital Status & $43 \%$ & $26 \%$ \\
Monogamy & $27 \%$ & $22 \%$ \\
Polygamy & $30 \%$ & $19 \%$ \\
Widow/er & & $28 \%$ \\
& & $49 \%$ \\
\hline Education & $15 \%$ & \\
Illiterate & & \\
Primary & & \\
Secondary & & \\
Tertiary & & \\
& & \\
\hline
\end{tabular}


Table 2: Distribution of households by cultivated land size by disease progression

\begin{tabular}{|c|c|c|c|c|}
\hline & Zero & $<1$ acre & 1-3 acre & $>3$ acre \\
\hline \multicolumn{5}{|l|}{ Stages of disease progression } \\
\hline Control ( $n=573)$ & $3 \%$ & $18 \%$ & $50 \%$ & $29 \%$ \\
\hline Stage 1 (no symptoms) $n=44$ & $4 \%$ & $24 \%$ & $47 \%$ & $24 \%$ \\
\hline $\begin{array}{l}\text { Stage } 2 \text { (symptomatic, CD4 > 200) } \\
n=48\end{array}$ & $7 \%$ & $17 \%$ & $67 \%$ & $9 \%$ \\
\hline $\begin{array}{l}\text { Stage } 3(\text { CD4 < } 200 \& \text { on ARVs) } \\
n=42\end{array}$ & $18 \%$ & $25 \%$ & $45 \%$ & $13 \%$ \\
\hline Stage 4 (Bed-ridden) $n=13$ & $8 \%$ & $15 \%$ & $54 \%$ & $23 \%$ \\
\hline Stage 5 (Death) $n=44$ & $0 \%$ & $9 \%$ & $64 \%$ & $27 \%$ \\
\hline
\end{tabular}

Table 3: Distribution of households by crops planted by disease progression

\begin{tabular}{|c|c|c|c|c|}
\hline & Maize & Beans & $\begin{array}{l}\text { Sorghum/ } \\
\text { Millet }\end{array}$ & $\begin{array}{l}\text { Cassava/ } \\
\text { Groundnuts }\end{array}$ \\
\hline \multicolumn{5}{|l|}{$\begin{array}{l}\text { Stages of disease } \\
\text { progression }\end{array}$} \\
\hline Control $(n=573)$ & $92 \%$ & $34 \%$ & $71 \%$ & $17 \%$ \\
\hline $\begin{array}{l}\text { Stage } 1 \text { (no symptoms) } \\
n=44\end{array}$ & $76 \%$ & $25 \%$ & $75 \%$ & $14 \%$ \\
\hline $\begin{array}{l}\text { Stage } 2 \text { (symptomatic, CD4 } \\
>200) n=48\end{array}$ & $91 \%$ & $28 \%$ & $83 \%$ & $15 \%$ \\
\hline $\begin{array}{l}\text { Stage } 3(C D 4<200 \& \text { on } \\
\text { ARVs) } n=42\end{array}$ & $73 \%$ & $23 \%$ & $58 \%$ & $13 \%$ \\
\hline Stage 4 (Bed-ridden) $n=13$ & $100 \%$ & $25 \%$ & $92 \%$ & $0 \%$ \\
\hline Stage 5 (Death) $n=44$ & $91 \%$ & $36 \%$ & $100 \%$ & $0 \%$ \\
\hline
\end{tabular}




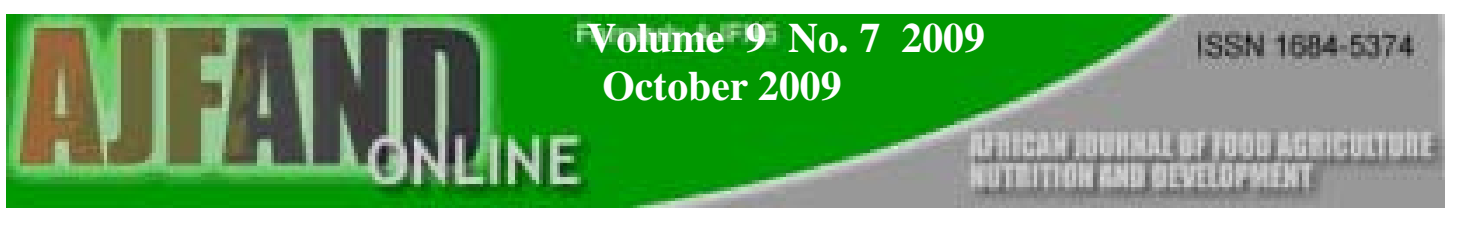

Table 4: Distribution of households by animals kept by disease progression

\begin{tabular}{|l|c|c|c|c|c|c|}
\hline \multicolumn{1}{|l|}{ Control } & Stage 1 & Stage 2 & Stage 3 & Stage 4 & Stage 5 \\
\hline Goats & & & & & & \\
\hline 0 & $43 \%$ & $58 \%$ & $61 \%$ & $56 \%$ & $50 \%$ & $55 \%$ \\
\hline 1 to 5 & $34 \%$ & $24 \%$ & $26 \%$ & $36 \%$ & $42 \%$ & $27 \%$ \\
\hline 6 to 10 & $17 \%$ & $13 \%$ & $7 \%$ & $8 \%$ & $0 \%$ & $9 \%$ \\
\hline 11 to 15 & $5 \%$ & $4 \%$ & $7 \%$ & $0 \%$ & $0 \%$ & $9 \%$ \\
\hline$>15$ & $2 \%$ & $0 \%$ & $0 \%$ & $0 \%$ & $8 \%$ & $0 \%$ \\
\hline Chicken & & & & & & \\
\hline 0 & $13 \%$ & $20 \%$ & $22 \%$ & $19 \%$ & $25 \%$ & $9 \%$ \\
\hline 1 to 5 & $29 \%$ & $36 \%$ & $29 \%$ & $28 \%$ & $17 \%$ & $36 \%$ \\
\hline 6 to 10 & $24 \%$ & $27 \%$ & $24 \%$ & $16 \%$ & $42 \%$ & $9 \%$ \\
\hline 11 to 15 & $9 \%$ & $9 \%$ & $14 \%$ & $21 \%$ & $8 \%$ & $18 \%$ \\
\hline$>15$ & $24 \%$ & $9 \%$ & $10 \%$ & $16 \%$ & $8 \%$ & $27 \%$ \\
\hline
\end{tabular}




\section{REFERENCES}

1. UNDP. Human Development Report. Cultural Liberty in Today's Diverse World. UNDP, New York, USA. 2004; 137-151.

2. UNAIDS. AIDS epidemic update, December 2004. Full text: http://www.unaids.org/wad2004/EPI_1204_pdf_en/EpiUpdate_en.pdf) 2004;a.

3. Oppong JR and J Gosh Concluding Remarks: Beyond Epidemiology. In Kalipeni E, Craddock S, Oppong JR and Gosh J (Eds). HIV and AIDS in Africa: beyond epidemiology. Blackwell, Oxford. 2004; 323-326.

4. Atieno RH, Owidi SA and PO Ochola Constraints And Policy Options to Women's Performance in Rural Development and Poverty Alleviation Towards The $21^{\text {st }}$ Century, The Kenyan Case. A paper presented at the Inter Regional seminar, Nairobi, Kenya, 16-18 ${ }^{\text {th }}$ June 1999.

5. FAO. HIV/AIDS, Agriculture and Food security in Mainland and Small Island Countries of Africa. Paper presented in the $22^{\text {nd }}$ regional conference for Africa. Cairo. 2002.

6. Semba RD and AM Tang Micronutrients and the pathogenesis of human immunodeficiency virus infection. British Journal of Nutrition 81:181189.1999

7. Kadonya C Impacts of HIV/AIDS on Smallholder Agriculture in Tanzania; Rethinking Of Other Interventions Strategies" Regional Conference For Eastern And Southern Africa On Responding To HIV/AIDS: Technology Development Needs Of African Smallholders Agriculture, Harare. 1998.

8. Engh I, Stloukal $\mathbf{L}$ and J Guen HIV/AIDS Namibia: The impact of the livestock sector. FAO, Rome. 2002.

9. FAO. The effect of HIV/AIDS on Faming Systems in Eastern Africa. FAO, Rome. 1995.

10. Lwanga D SARA project/Commonwealth Regional Community Secretariat for East, Central and Southern Africa. Nutrition Briefs: HIV/AIDS and nutrition. June 2001.

11. Kwaramba $\mathbf{P}$ "The social - Economic Impact of HIV/AIDS on communal Agricultural Systems in Zimbabwe. Zimbabwe Farmers Union, Freidirich Ebert Stftung economic advisory project, working paper. Harare, Zimbabwe. 1997 ,

12. Barnett $\mathbf{T}$ and $\mathbf{M}$ Haslwimmer The Effects of HIV/AIDS on Farming Systems in Eastern Africa. FAO, Rome. 1995. 
13. Rugalema G HIV/AIDS and the Commercial Agricultural Sector of Kenya: Impact, Vulnerability and Coping Strategies. FAO, New York. 1999.

14. Piwoz E and E Preble HIV/AIDS and Nutrition: A Review of the Literature and Recommendations for Nutritional Care and Support in Sub-Saharan Africa for SARA Project and U.S. Agency International Development. Washington D.C. 2000.

15. Administrative Committee on coordination/Subcommittee on Nutrition of the United Nations. Overview to the feature: Nutrition and HIV/AIDS. SCN News. 1998; 17:3-4.

16. Mugenda OM and AG Mugenda Research Methods Qualitative and Quantitative Approaches. African Centre for Technology Studies press, Nairobi, Kenya.1999.

17. UNAIDS. AIDS Epidemic Update. Full text: http://www.unaids.org/ en_/resources/Publications/Corporate +Publications/AIDS +epidemic + update + -+December+2003. asp 2003.

18. Michiels SI Strategic Approaches to HIV prevention and AIDS mitigation in Rural Communities and Households in Sub-Saharan Africa. Rome, FAO. April 2001.

19. White J and E Robinson HIV/AIDS and Rural Livelihoods in Sub-Saharan Africa. Chatham, UK: Natural Resources Institute. 2000. Policy Series 6.

20. Englund $\mathbf{H}$ The Village In The City, The City In The Village: Migrants In Lilongwe. Journal of Southern African Studies. 2002; 28 (1):137-154. 